\title{
RANCANG BANGUN APLIKASI KAMUSBAHASAINDONESIA - BAHASA ACEH MENGGUNAKAN METODE RULE BASED BERBASIS ANDROID
}

Design And Development Of Kamusbahasaindonesia - Aceh Language Using Android Based Rule Method

\author{
Riska Pebrijayanti $^{(1)}$, Zalfie Ardian $^{(2)}$ \\ S-1 Teknik Informatika Fakultas Ilmu Komputer, Universitas Ubudiyah Indonesia \\ Jl. Alue Naga, Tibang, Kec. Syiah Kuala, Banda Aceh-Indonesia \\ Email: $\underline{\text { riskapebrijayanti@gmail.com }}{ }^{(1)}$, zalfie.ardian@ uui.ac.id $^{(2)}$
}

Bahasa merupakan sarana untuk berkomunikasi. Pengetahuan tentang bahasa sangatlah penting karena dalam percakapan atau pembicaraan memerlukan sebuah bahasa. Di Indonesia banyak sekali bahasa daerah, antara lain bahasa Aceh.Setelah tsunami, Aceh mengalami perubahan besar. Salah satu perubahaan yang dapat kita lihat adalah Provinsi Aceh menjadi salah satu tujuan wisata di Indonesia, hal ini tentunya banyak menarik wisatawan untuk berkunjung ke Aceh.Namun hal ini tidak diimbangi dengan kemampuan wisatawan dalam memahami bahasa Aceh.Bahasa juga mulai terkikis dengan perkembangan sehingga banyak generasi Aceh sekarang kurang memahami bahasa daerahnya sendiri.Maka, salah satu sarana untuk mempelajari bahasa Aceh yaitu dengan menggunakan kamus. Ada banyak sekali jenis kamus mulai dari kamus berbentuk buku sampai berbentuk aplikasi smartphone.Seiring semakin banyak pengguna smartphone berbasisandroid, maka dirancanglah aplikasi kamus AcehI ini.Tujuan pembuatan aplikasi kamus AcehI adalah membantu pengguna dalam mempermudah pencarian kosakata dalam bahasa Aceh.Metode pembuatan aplikasi yaitu menggunakan metode Rule Based.Aplikasi ini dirancang dengan menggunakan Eclipse sebagai media pembuatannya, SQLite sebagai database penyimpanan kata dan kemudian diimplementasikan ke smartphone berbasis android.

Kata kunci : Kamus, AcehI, Smartphone, Android, Eclipse, SQlite.

\section{PENDAHULUAN}

\subsection{LatarBelakang}

Bahasa daerah merupakan warisan budaya yang saat ini terancam punah, menurut beberapa sumber indonesia memiliki lebih dari 300 bahasa daerah, yang mulai mendapatkan perhatian dari banyak kalangan karena kebudayaan yang semakin berkembang dimasyarakat, salah satunya bahasa daerah Aceh yang ada di Provinsi Aceh. Dalam pergaulan sehari-hari masyarakat Aceh menggunakan bahasa daerah setempat, tetapi seiring perkembangan zaman, banyaknya pendatang yang terus berdatangan membuat bahasa daerah setempat terancam keberadaannya. Hal ini menjadi suatu masalah yang harus ditanggulangi sedini mungkin agar bahasa daerah khususnya bahasa daerah Aceh tetap lestari dilingkungannya

Dari penjelasan diatas, maka dibutuhkan cara agar dapat membantu memecahkan masalahmasalah tersebut, untuk itu dirancanglah Aplikasi Kamus Bahasa Indonesia - Bahasa Aceh Menggunakan Metode Rule Based Berbasis Android yang dinamakan AcehI.AcehI merupakan sebuah aplikasi yang dapat menerjemahkan kata dalam bahasa Aceh ke Bahasa Indonesia, berlaku sebaliknya.

\subsection{RumusanMasalah}

Berdasarkan latar belakang masalah yang telah diuraikan di atas maka dapat dirumuskan beberapa permasalahan yaitu:

1. Seiring perkembangan zaman budaya Bahasa Aceh mulai punah.

2. Setelah tsunami banyak wisatawan yang datang ke Aceh, hal ini tidak diimbangi kemampuan wisatawan dalam berbahasa begitu pula sebaliknya.

Dari permasalahan yang telah dirumuskan, sebagai solusi adalah bagaimana membuat suatu kamus dengan memanfaatkan teknologi android untuk memudahkan pencarian kata dari bahasa Aceh ke bahasa Indonesia maupun sebaliknya.

\subsection{BatasanMasalah}

Pada penelitian ini dapat diidentifikasi beberapa batasan masalah diantaranya:

1. Aplikasi ini dapat berjalan pada Android versi 2.1(éclair) dan versi selanjutnya

2. Aplikasi kamus ini dapat menerjemahkan bahasa Indonesia ke bahasa Aceh berlaku sebaliknya. 
3. Aplikasi ini hanya dapat menerjemahkan kata, bukan menerjemahkan kalimat.

4. Aplikasi berjalan dalam kondisi offline.

5. Kata-kata yang telah dimasukkan kedalam database tidak dapat ditambahkan oleh user.

\subsection{TujuanPenelitian}

Tujuan dari perancangan aplikasi ini adalah melestarikan budaya bahasa Aceh dengan membuat sebuah aplikasi kamus berbasis android yang dapat menerjemahkan kata-kata dalam bahasa Aceh ke bahasa Indonesia maupun sebaliknya.

\subsection{ManfaatPenelitian}

Terdapat beberapa manfaat dalam penelitian ini, diantaranya :

1. Perancangan aplikasi ini memprioritaskan kemudahan seseorang dalam menemukan kata terjemahan Bahasa Aceh menjadi Bahasa Indonesia dan sebaliknya.

2. Membantu dalam hal proses terjemahan arti dalam bahasa Aceh.

3. Mengenalkan budaya bahasa Aceh.

\subsection{KeaslianPenelitian}

Viska Mutiawani dkk dari Universitas Syiah Kuala Banda Aceh pada tahun 2009 pernah melakukan penelitian dengan judul "AplikasiKamus Dwibahasa Aceh-Indonesia Berbasis JavaUntuk Telepon Genggam”.Dalam penelitian ini metode yang digunakan yaitu metode RapidApplication Development $(R A D)$.

I Putu Deni Pratama dan Agus Muliantara dari Universitas Udayana Bali melakukan penelitian yang berjudul "Perancangan dan Implementasi Sistem Penerjemah Teks Bahasa

Inggris Ke Bahasa Bali Dengan Menggunakan Pendekatan Berbasis Aturan (Rule Based)" pada tahun 2012

Zalfie Ardian dari Universitas Gajah Mada

pada tahun 2014 dengan judul tesisnya "Argot : Sistem Pendeteksian Berbasis Text Secara Real Time Menggunakan Augment Reality Sebagai Media Translator Aceh-Indonesia dengan Smartphone Berbasis Android". Dalam penelitian ini konsep yang digunakan yaitu konsep teknologi Augment Reality (AR) yang masih jarang digunakan pada marker berbasis teks.

\section{TINJAUANPUSTAKA}

\subsection{Definisi Aplikasi}

Menurut Jogiyanto (1999) aplikasi adalah penggunaan dalam suatu komputer, intruksi (instruction) atau pernyataan (statement) yang disusun sedemikin rupa sehingga computer dapat memproses input menjadi output. Sedangkan menurut Kamus Besar Bahasa Indonesia (1998) aplikasi adalah penerapan dari rancang sistemuntuk mengolah data yang menggunakan aturan atau ketentuan bahasa pemogaraman tertentu.Aplikasi adalah suatu program komputer yang dibuat untuk mengerjakan dan melaksanakan tugas khusus dari pengguna.

\subsection{Metode Rule Based}

Teknikinimenggunakan aturan-aturan bahasabakudalammenerjemahkan.Selainaturan aturan, diperlukanjugadatakamusuntuktiapkata dalamduabahasa.Jaditiapkataditerjemahkan satupersatu,kemudian diaturlagiberdasarkan aturanbahasabaku.ContohaplikasiRuleBased iniyaitureksotranslator.Sistem berdasarkan pengetahuan lingusitik.Kelebihannyaadalah mampumenganalisa padatingkatansintaksisdan semantik secaralebihmendalam. Kelemahannya membutuhkan pengetahuan bahasa(Aceh, Indonesia) yang baiksertatidakmungkin menuliskan aturanyangmencakupsemuabahasa.(Trya,2015).

\subsection{Definisi Bahasa}

Bahasa pada hakikatnya adalah ucapan pikiran dan perasan manusia secara teratur, yang mempergunakan bunyi sebagai alatnya (Depdiknas, 2005). Namun, menurut Harun Rasyid, Mansyur \& Suratno (2009) bahasa merupakan struktur dan makna yang bebas dari penggunanya, sebagai tanda yang menyimpulkan suatu tujuan. Sedangkan menurut kamus besar Bahasa Indonesia bahasa berarti sistem lambang bunyi yang arbitrer, yang digunakan oleh semua orang atau anggota masyarakat untuk bekerjasama,

berinteraksi, dan mengidentifikasi diri dalam bentuk percakapan yang baik, tingkah laku yang baik, sopan santun yang baik (Hasan Alwi, 2002).

\subsection{Definisi Android}

Androidadalahsistemoperasiuntukperangkat mobileberbasisLinuxyang mencakup sistem operasi,middleware, danaplikasi.Androidmenyedia kanplatformterbuka bagi para pengembangbuatmenciptakanaplikasimerekasendir iuntukdigunakan olehbermacam perantibergerak. 


\subsection{Perangkat yang digunakan}

Dalam perancangan aplikasi diperlukan perangkat pendukung. Dibawah ini beberapa perangkat yang akan digunakan sebagai editor maupun emulator.

\subsubsection{Eclipse}

Eclipseadalah

sebuah

IDE(IntegratedDevelopment

Environment)untukmengembangkanperangkatlunak dandapatdijalankandisemua platform (platformindependent).

\subsubsection{Java}

Javamerupakan bahasa berorientasi objek(OOP)yaitucara ampuh dalam pengorganisasiandanpengembanganperangkatlunak. PadaOOP,program komputer sebagaikelompokobjekyangsalingberinteraksi.Deskr ipsi ringkasOOPadalah mengorganisasikan program sebagai kumpulankomponen, disebut objek.

\subsubsection{AndroidSDK (Software Defelopment Kit) AndroidSDKadalah} toolsAPI(ApplicationProgrammingInterface) yang diperlukanuntukmulaimengembangkanaplikasipada platform Android

menggunakanbahasapemrogramanJava.

\subsubsection{Database}

Secarasederhanadatabase (basis

data)

dapatdiungkapkansebagaisuatu

pengorganisasiandatadengan

bantuankomputeryangmemungkinkandatadapat

diaksesdenganmudahdan

cepat.Dalamhalini,pengertianaksesdapatmencakup pemerolehan data maupun pemanipulasian data, seperti menambah, mengedit, mengupdatedatadanmenghapusdata

darisebuahtabelmaupundaribeberapa table.

\subsubsection{SQLite Browser}

\section{SQLitemerupakanmesin}

databaseSQLembedded.Tidak sepertikebanyakan database

SQLlainnya, SQLitetidakmemilikiprosesserveryangterpisah.SQL ite membacadanmenulissecaralangsungkedisk.

\section{Metode Penelitian}

\subsection{Jenis Penelitian}

Penelitian ini dilakukan menggunakan metode kuantitatif yaitu berdasarkan metodologi yang menghasilkan dan mengumpulkan data-data, bertujuan menggambarkan secara sistemastis dan akurat mengenai data-data yang ada dengan cara mengumpulkan dan mengklasifikasikan data yang diperoleh kemudian dianalisis dengan teori dipelajari. Penelitian kuantitatif dilakukan pada kondisi alamiah dan bersifat penemuan.

\subsection{Lokasi dan Waktu Penelitian}

Pembuatan Aplikasi Kamus Bahasa Aceh Bahasa Indonesia berbasis Android ini dilaksanakan pada bulan Oktober 2015 sampai dengan Februari 2016 yang bertempat di Universitas Ubudiah Indonesia Jalan Alue Naga Desa Tibang Krueng Banda Aceh.

\subsection{Alat dan Bahan}

Dalam perancangan kamus Bahasa Aceh Indonesia ini diperlukan perangkat keras dan perangkat lunak sebagai pendukung, antara lain sebagai berikut :

\subsubsection{Perangkat Keras}

Dalam perancangan aplikasi kamus Bahasa Aceh - Indonesia ini, perangkat yang digunakan adalah 1 (satu) unit laptop Compaq dengan spesifikasi sebagai berikut:

a. Processor : Intel(R) Core(TM)2 Duo CPU T5870@2.00GHz

b. RAM : 3.00GB

c. Operating system : Windows 7 32-Bit

Sedangkan dalam pengimplementasian aplikasi kamus Bahasa Aceh - Indonesia ini, perangkat yang digunakan adalah 1 (satu) unit smartphone dengan spesifikasi sebagai berikut:

a. Smartphone berbasis android versi 4.2.2 (Jelly Bean)

b. Processor : Dual Core $1,3 \mathrm{GHz}$ RAM : 1.00GB

\subsubsection{Perangkat Lunak}

1. jdk-7u40-windows-i586

2. BlueStacks

3. Eclips

4. SQLite Browser

5. Android SDK Manager

\subsection{Tahapan Penelitian}

Tahapan penelitian merupakan salah satu tahap yang paling penting dalam proses pembuatan program aplikasi. Tujuannya adalah untuk mendefinisikan jalannya proses yang ada dalam suatu sistem. Proses yang masuk maupun yang keluar dari sistem. 
Journal of Informatics and Computer Science Vol. 4 No. 1 April 2018

Universitas Ubudiyah Indonesia

e-ISSN : 2615-5346

\subsubsection{Rancangan Aplikasi (Flowchart)}

Struktur sistem informasi yang akan dirancang terlebih dahulu dianalisa, sehingga gambaran yang akan dikemukakan dapat divisualisasikan dalam bentuk rancangan aplikasi(flowchart).Flowchartuntuk Aplikasi Kamus Bahasa Aceh -Bahasa Indonesia MenggunakanMetode Rule Based Berbasis Android terlihat pada Gambar 3.1, diagram jalannya penelitian.

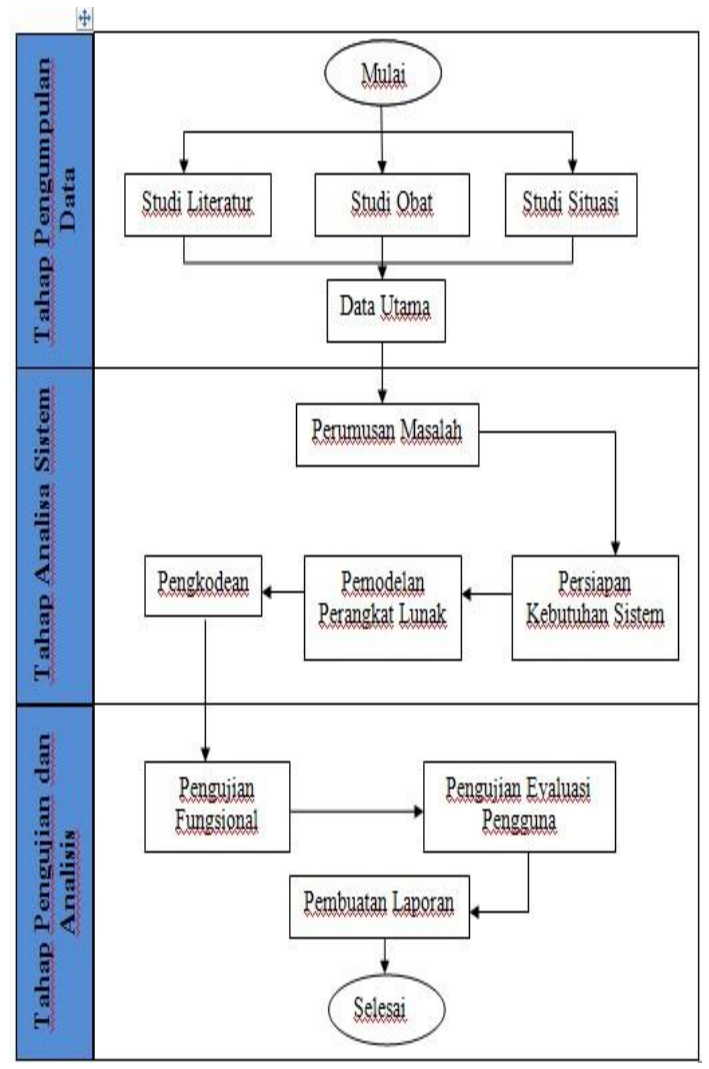

Gambar 3.1 Diagram Alur Penelitian

\subsubsection{Deskripsi Aplikasi}

Aplikasi ini diharapkan mampu berjalan dengan sempurna pada smartphone, dengan model rancangan seperti pada Gambar 3.2.

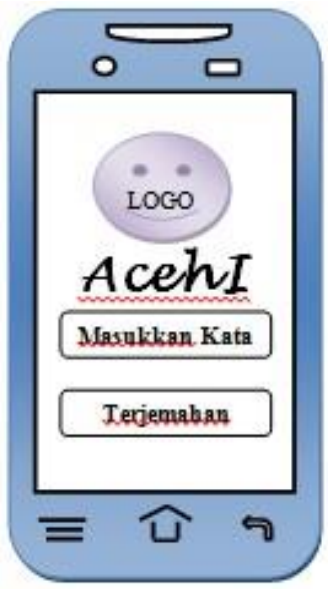

Gambar 3.2 Ilustrasi Tampilan Aplikasi

\subsubsection{Desain Sistem Aplikasi}

Gambaran umum interaksi dari sistem AcehI dapat dilihat pada Gambar 3.3 sehingga memudahkan para pengguna dalam mengoperasikan aplikasi yang akan dirancang.

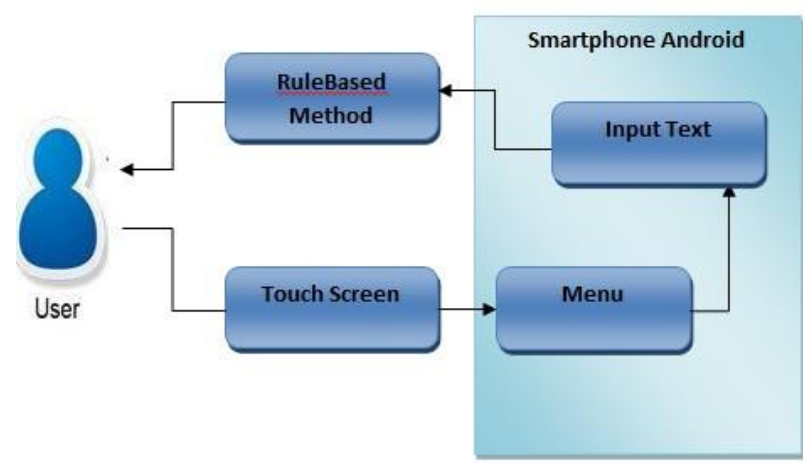

Gambar 3.3. Gambaran Umum Sistem

Userdapatberinteraksisecararealtime denganmenyentuh layar touchscreenuntukmengaktifkanpilihantranslatebah asa,lalu menginput kata-kata sehingga secara otomatis diterjemahkan dengan metode rulebased danakan ditampilkan melalui layar smartphone android.

\subsubsection{Rancangan Flowchart Sistem}

Gambar dibawah ini merupakan rancangan sistem pada level 0 .

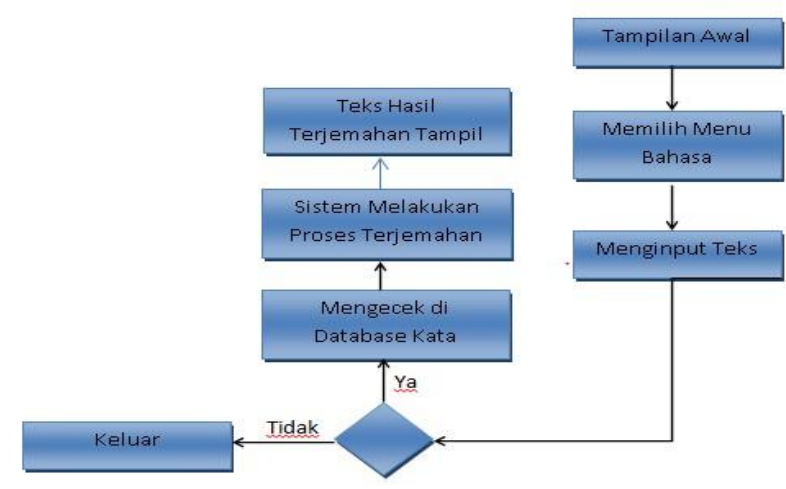

Gambar 3.4 Flowchart Level 0

Gambar

diatas

ketikaprosespenginputanteks, munculterjemahantekstersebutpada menjelaskan $\mathrm{m}$ a k a layar smartphonedengan catatanteks tersebut ada pada database kata-kata. Teks munculsecararealtime hanya dengan mengklik button terjemahkan , sehinggalebihpraktisdanjuga userakanmerasa nyaman menggunakannya. 
Journal of Informatics and Computer Science Vol. 4 No. 1 April 2018

Universitas Ubudiyah Indonesia

e-ISSN : 2615-5346

Gambar dibawah ini merupakan rancangan system pada level 1.Alurinteraksi dengan sistemAcehIadalah sebagai berikut.

a.

teks,jikateksdikenalimakasistem akan mencari kata dalamteks tersebut dalam databaseyangtersedia.

b.

Sistemkemudianakanmenampilkanteksterjemah ansecararealtimejika teksyang diinginkan terdapat dalam database.

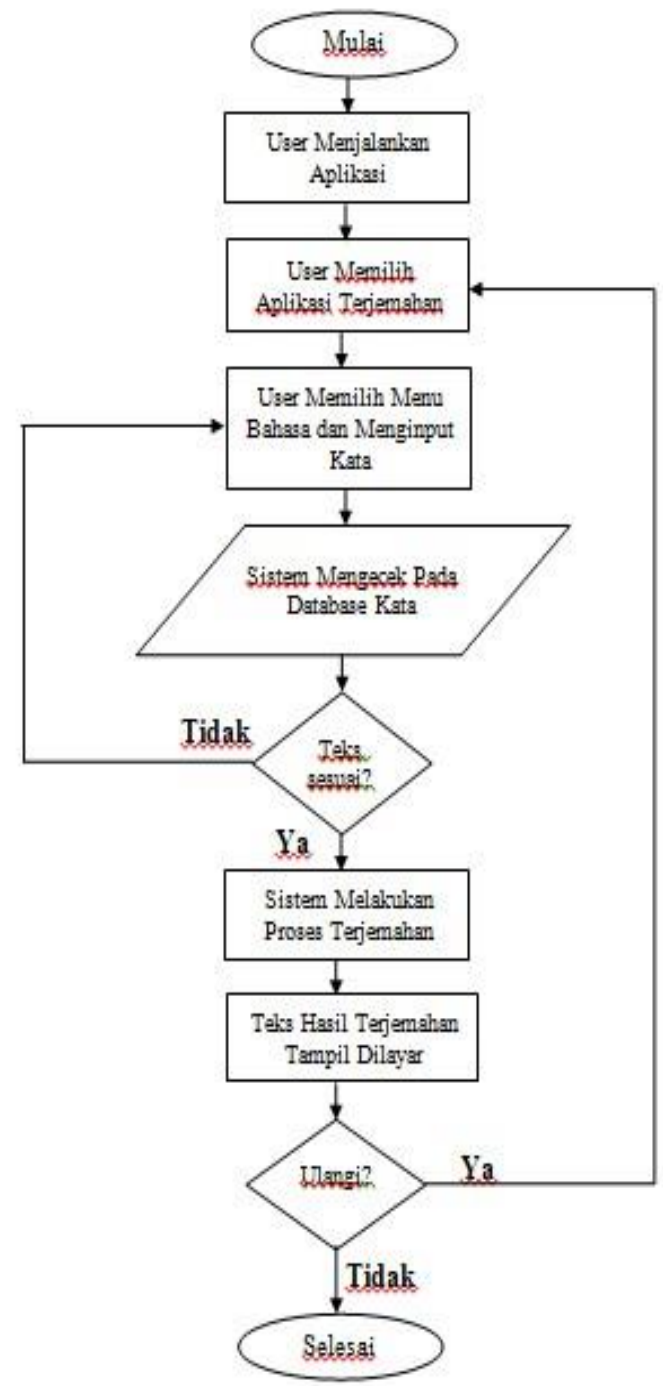

Gambar 3.5Flowchart Sistem AcehI Level 1

Flowchart diatas menjelaskan tentang proses jalannya sistem aplikasi kamus Bahasa Indonesia - Bahasa Aceh berbasis android, dimulai dari membuka aplikasi lalu memilih menu bahasa yang akan digunakan dan menginput kata yang ingin diterjemahkan sampai dengan hasil inputan tampil dilayar smartphone.

Gambar berikut ini merupakan Use Case Diagram, yang menggambarkan kebutuhan sistem dari sudut $u$ ser.

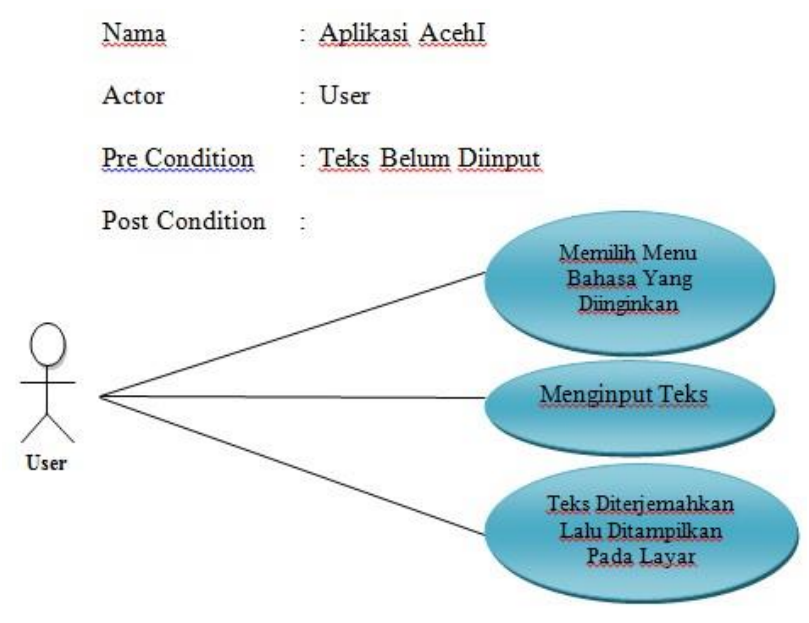

Gambar 3.6Use Case Diagram

Diagram Use Case sistem aplikasi kamus Bahasa Aceh - Indonesia berbasis Android pada Gambar 3.6 menjelaskan interaksi antara use case dan actor. Actor user memberikan arah panah ke beberapa use case, antara lain : Actor User dapat memilih menu bahasa yang diinginkan, Actor User juga dapat menginput teks sesuai dengan menu bahasa yang telah dipilih, dan terakhir Actor User dapat memilih menu terjemah yang dapat menampilkan hasil terjemahan teks yang telah diinput.

osting saatinimendukung adanyaPHPdan MySQLkarenakecepatan, gratis,dandapatdi jalankandisistem operasimanapun. (Loka Dwiartara, 6:2010).

Dari pendapatparah ahli diatas, maka dapatdisimpulkan bahwaMySQL adalah sebuah database yang menyimpan berbagai informasi yangsalingberkaitan satu dengan yanglainnya.

\section{Implementasi dan Pengujian Sistem \\ 4.1. Implementasi Sistem}

Tujuan implementasi adalah untuk menerapkan perancangan yang telah dilakukan terhadap sistem sehingga user dapat memberi masukan demi berkembangnya sistem yang telah dibangun sebagai simulasi dari aplikasi kamus Bahasa Aceh - Indonesia berbasis android yang diberi namaAcehI.

\subsubsection{Implementasi Basis Data}

Pembuatan database dilakukan dengan menggunakan program SQLite Browser. Implementasi database dalam bahasa SQL adalah sebagai berikut :

\begin{tabular}{|l|}
\hline \multicolumn{1}{|c|}{ Database Kata } \\
\hline CREATE TABLE 'kata'( \\
'id INTEGER PRIMARY KEY AUTOINCREMENT, \\
'indonesia' TEXT, \\
aceh' TEXT, \\
'aceh non_simbol' TEXT, \\
);
\end{tabular}


Berikut ini merupakan script untuk mengimport database dari Eclipse ke SQLite Browser :

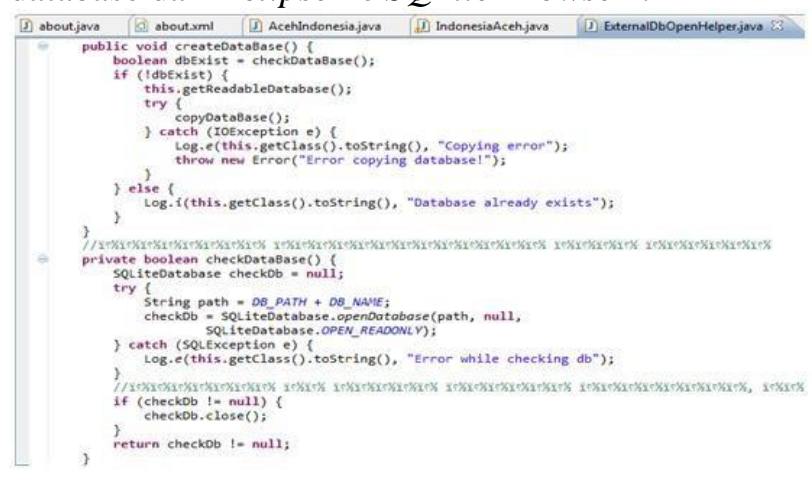

\subsubsection{Implementasi Antar Muka (Interface)}

Aplikasi AcehI merupakan aplikasi yang berfungsi sebagai aplikasi penerjemah bahasa. Untuk mengoperasikan aplikasi ini, terdapat beberapa tahapan yang dibuat untuk mempermudah user dalam proses penggunaannya. Adapun tahapan - tahapan tersebut adalah sebagai berikut .

\subsubsection{Tampilan Splash Screen}

Tampilan Splash Screen adalah sebuah tampilan yang muncul saat pertama kali membuat suatu aplikasi, splash screen tidak bersifat tetap, melainkan akan menghilang perlahan - lahan seiring dengan munculnya aplikasi pada menu utama. Tampilan splash screen dapat dilihat pada Gambar 4.1.

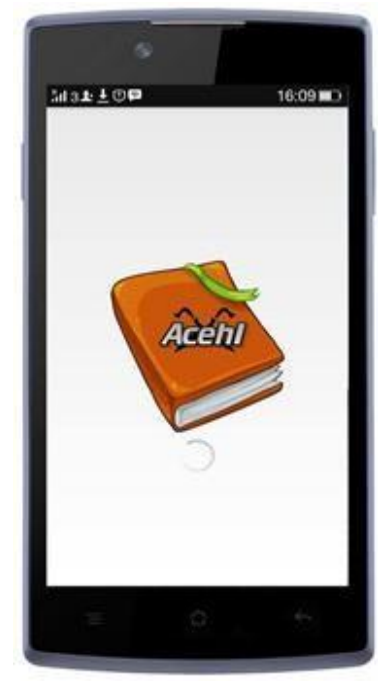

Gambar 4.1 Tampilan Layar Splash Screen

Berikut ini merupakan script untuk merancang tampilan splash screen, pada script tersebut terdapat durasi untuk mengetahui lamanya proses splash screen.

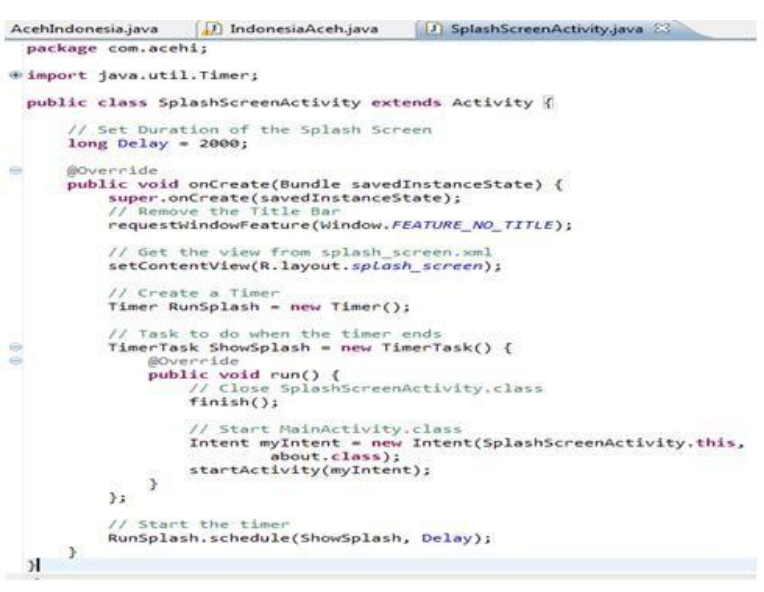

\subsubsection{Tampilan Petunjuk Penggunaan}

Tampilan petunjuk penggunaan ini berisi tentang manfaat, petunjuk pemakaian dan hak cipta aplikasi.

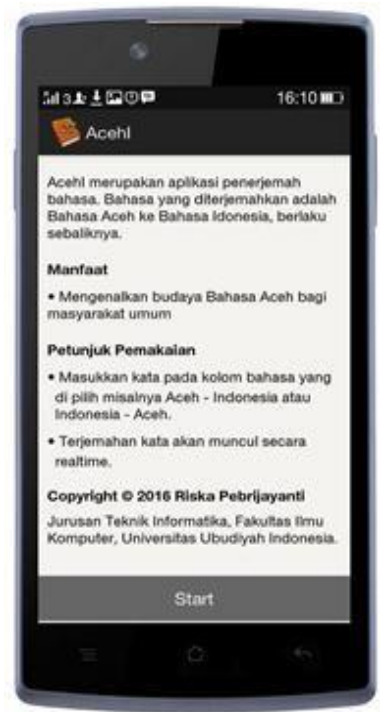

Gambar 4.2 Tampilan Petunjuk Penggunaan

Berikut ini merupakan script untuk merancang interfacepetunjuk penggunaan.

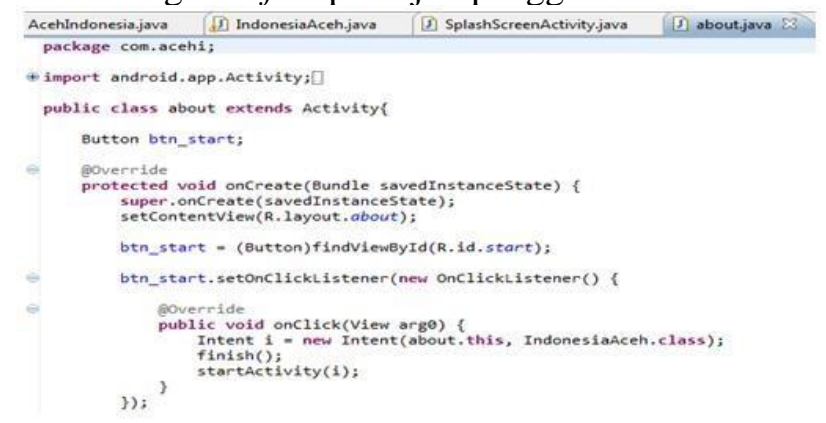

\subsubsection{Tampilan Proses Penerjemahan}

Halaman menu Aceh - Indonesia menampilkan sebuah kotak inputan dan sebuah kotak hasil terjemahan.User dapat menginput kata sesuai dengan bahasa yang di inginkan tanpa meyentuh tombol apapun, hasil terjemahan akan 
Journal of Informatics and Computer Science Vol. 4 No. 1 April 2018

Universitas Ubudiyah Indonesia

e-ISSN : 2615-5346

muncul secara real time. Jika user ingin mengganti

bahasa maka user dapat mengklik tombol button

yang ada di bawah kotak hasil terjemahan. 
Journal of Informatics and Computer Science Vol. 4 No. 1 April 2018

Universitas Ubudiyah Indonesia

e-ISSN : 2615-5346
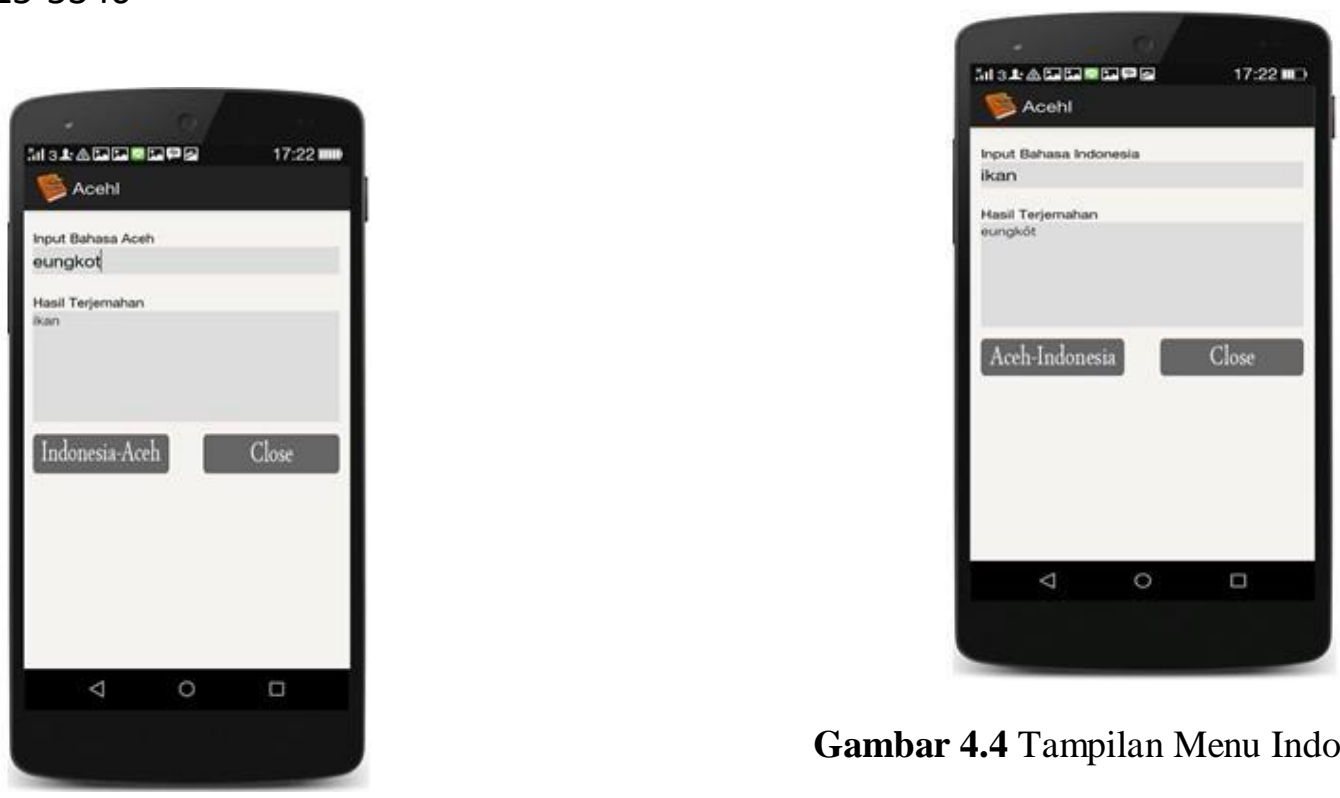

Gambar 4.4 Tampilan Menu Indonesia - Aceh

Gambar 4.3 Tampilan Menu Aceh - Indonesia

Berikut ini merupakan script untuk merancang interface menu Aceh - Indonesia.

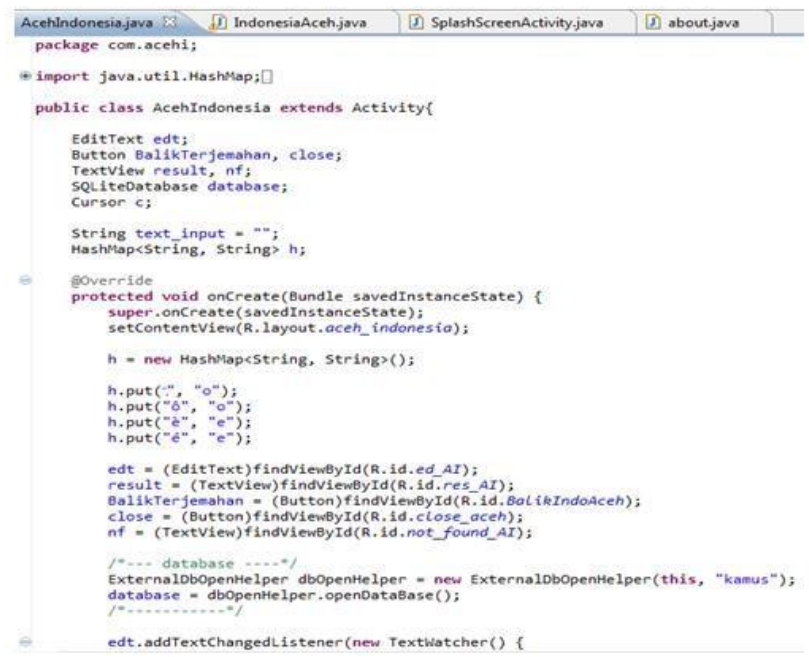

\subsubsection{Tampilan Petunjuk Penggunaan}

Tampilan petunjuk penggunaan ini berisi tentang manfaat, petunjuk pemakaian dan hak cipta aplikasi. 
Berikut ini merupakan script untuk merancang interface menu Indonesia - Aceh.

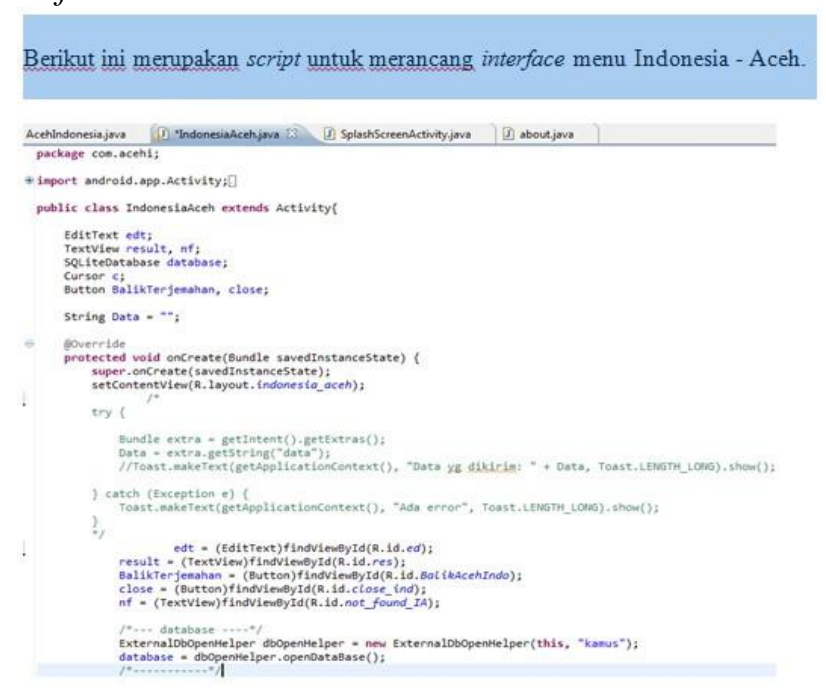

\subsection{Pengujian Sistem}

Pengujian sistem adalah pengecekan dari jaminan kualitas perangkat lunak dan merepresentasikan kajian pokok dari spesifikasi, perancangan, dan pengkodean.Pengujian yang digunakan untuk menguji sistem ini adalah metode pengujian black-box.Pengujian black-box berfokus pada persyaratan fungsional perangkat lunak.

\subsubsection{Perangkat Pengujian Sistem}

Perangkat pengujian sistem aplikasi dengan menggunakan smartphone dengan spesifikasi smartphone android (OPPO) dengan versi 4.2.2 (Jelly Bean) dan RAM 1 GB.

\subsubsection{Tahapan Pengujian Sistem}

Berdasarkan rencana pengujian yang telah disusun, maka dapat dilakukan tahapan pengujian sebagai berikut :
1. Pengujian Database Sistem
2. Pengujian Fitur Utama
3. Pengujian Kelayakan Aplikasi

\subsubsection{Pengujian Database Sistem}

Pengujian database sistem pada aplikasi AcehImenggunakan SQLite Browser sebagai media penyimpanan data.Data yang disimpan berupa kata dengan huruf alphabet maupun simbol. 
Universitas Ubudiyah Indonesia
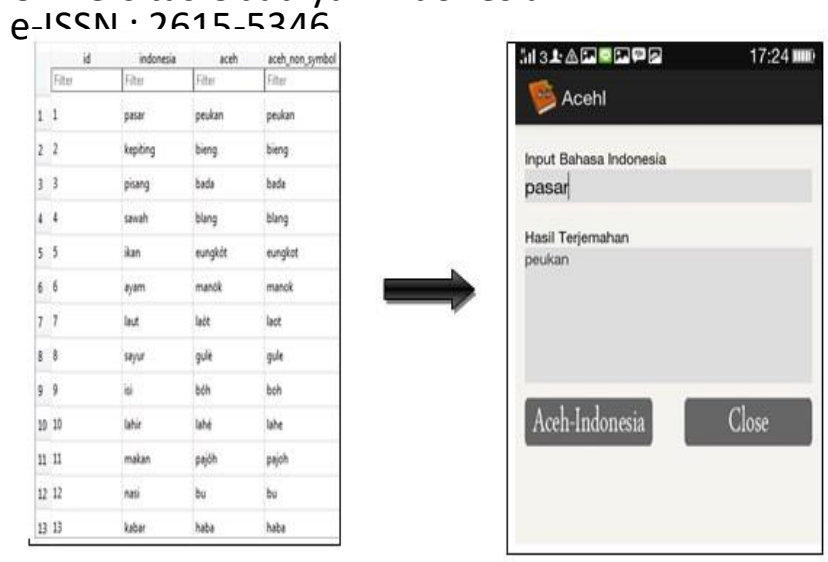

Gambar 4.5.Pengujian Database Sistem

Pada Gambar 4.5 dapat dilihat bahwa kata yang telah diinput ke database akan muncul ketika proses terjemahan dilakukan oleh user. Aplikasi AcehI tidak menyediakan opsi tambah kata, jadi hanya admin yang dapat menambah maupun mengubah kata yang ada dalam database. Jika kata tidak ada dalam database maka akan muncul pemberitahuan "kata tidak ditemukan" pada kotak terjemahan.

\subsubsection{Pengujian Fitur Utama}

Pengujian fitur utama merupakan proses uji coba aplikasi AcehI berpindah dari satu halaman ke halaman selanjutnya sesuai dengan perintah user. Pengujian ini akan dilakukan pada halaman petunjuk penggunaan aplikasi yang akan berpindah ke halaman menu Indonesia - Aceh. Pengujian fitur utama dapat dilihat pada Gambar 4.6.

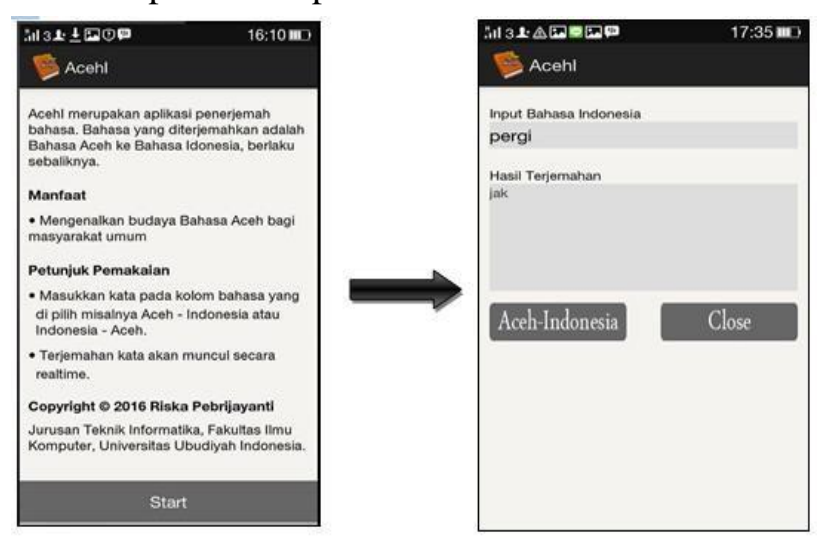

Gambar 4.6Pengujian Fitur Utama

Ketika user ingin beralih ke halaman selanjutnya maka user dapat mengklik button "Start" dan otomatis aplikasi akan berpindah ke halaman selanjutnya. Jika user ingin beralih bahasa maka user dapat mengklik button dibawah kotak terjemahan. Dan jika ingin meakhiri proses terjemahan, user dapat mengklik button "Close".

\subsubsection{Uji Kelayakan Sistem}

Pengujian dilakukan dengan tujuan untuk mengetahui sejauh mana kualitas dari aplikasi yang dirancang, apakah sudah sesuai dengan harapan atau 
e-ISSN : 2615-5346

belum. Untuk itu dalam uji kelayakan sistem dilakukan penelitian dengan cara menentukan populasi dan sampel. Populasi dalam penelitian ini adalah seluruh mahasiswa Universitas Ubudiyah Indonesia yang berstatus aktif, yang berjumlah 600 orang dari semua angkatan.

Adapun sampel yang diambil pada penelitian ini menggunakan teknik random sampling, teknik ini digunakan karena populasinya

tidak homogen.Maksudnya, subjek dalam populasi berbeda dari segi angkatan dan jurusan. Penelitian

ini menggunakan kuisioner yang akan dibagi kepada

mahasiswa Universitas Ubudiah

Indonesia.

Jumlah anggota sampel ditentukan menggunakan Rumus Taro Yaname dan Slovin.Adapun rumus tersebut adalah sebagai berikut :

$$
\mathrm{n}=\frac{\mathrm{N}}{\mathrm{Nd}^{2}+1}
$$

Dimana :

n. Jumlah anggota sampel

N : Jumlah populasi

d. Tingkat kepercayaan / kesalahan yang di kehendaki $\rightarrow$ ditetapkan $18 \%$.

Maka:

$$
\mathrm{n}=\frac{\mathrm{N}}{\mathrm{Nd}^{2}+1}=\frac{600}{600(0.18)^{2}+1}=\frac{600}{20,44}=29,35=30 \text { Orang }
$$

Jadi, jumlah anggota sampel yang akan diberikan kuisioner adalah 30 orang responden. Kuisioner kemudian akan dibagikan ke dua jurusan yang berbeda yaitu Teknik Informatika (TI) dan Sistem Informasi (SI). Isi kuisioner terdiri dari informasi umum responden, pertanyaan kepuasan responden dan kolom komentar (kuisioner terlampir).

\section{a) Korelasi Pearson Product}

\section{Moment}

Analisis ini dengan cara mengkorelasikan masing-masing skor item dengan skor total (penjumlahan seluruh skor item). Rumus untuk menghitungnya

adalah : 
Keterangan:

$$
\begin{aligned}
& \text { = koefisien korelasi item - total (bivariate } \\
& \text { pearson) } \\
& \mathrm{i}=\text { skor item } \\
& \mathrm{x}=\text { skor total } \\
& \mathrm{n}=\text { banyak nya subjek }
\end{aligned}
$$

\begin{tabular}{|c|c|c|c|c|c|c|c|c|}
\hline \multirow{2}{*}{ No } & \multirow{2}{*}{ Ukur } & \multicolumn{7}{|c|}{ Item } \\
\hline & & 1 & 2 & 3 & 4 & 5 & 6 & 7 \\
\hline 1 & $\mathrm{n}$ & 30 & 30 & 30 & 30 & 30 & 30 & 30 \\
\hline 2 & $\sum i$ & 132 & 126 & 139 & 137 & 142 & 138 & 138 \\
\hline 3 & $\sum x$ & 952 & 952 & 952 & 952 & 952 & 952 & 952 \\
\hline 4 & $\sum \mathrm{ix}$ & 4214 & 4020 & 4437 & 4375 & 4526 & 4403 & 4403 \\
\hline 5 & $\sum i^{\wedge} \mathbf{2}$ & 590 & 538 & 651 & 635 & 678 & 642 & 642 \\
\hline 6 & $\sum x^{\wedge} \mathbf{2}$ & 30378 & 30378 & 30378 & 30378 & 30378 & 30378 & 30378 \\
\hline 7 & $\left(\sum i\right)^{\wedge} \mathbf{2}$ & 17424 & 15876 & 19321 & 18769 & 20164 & 19044 & 19044 \\
\hline 8 & $\left(\sum x\right)^{\wedge} \mathbf{2}$ & 906304 & 906304 & 906304 & 906304 & 906304 & 906304 & 906304 \\
\hline \multicolumn{2}{|c|}{ Korelasi (r-ix) } & 0.6412 & 0.5619 & 0.7622 & 0.6943 & 0.6330 & 0.6845 & 0.6845 \\
\hline
\end{tabular}

\section{Tabel 4.1Tabel Perhitungan Nilai Korelasi}

Tabel hasil korelasi disesuaikan dengan tabel ketentuan Koefisen korelasi Pearson dibawah ini :

Tabel 4.2 Tabel Koefisien korelasi Pearson Pada Uji Validitas dan Reliabilitas

\begin{tabular}{|c|c|}
\hline Ketentuan & Penilaian \\
\hline Antara 0,800 sampai dengan 1,00 & Sangat tinggi \\
\hline Antara 0,600 sampai dengan 0,800 & Tinggi \\
\hline Antara 0,400 sampai dengan 0,600 & Cukup \\
\hline Antara 0,200 sampai dengan 0,400 & Rendah \\
\hline Antara 0,00 sampai dengan 0,200 & Sangat Rendah \\
\hline
\end{tabular}

Dengan adanya ketentuan dan penilaian pada koefisien korelasi pearsonsehingga pada uji Validitas dan Reliabilitas dapat dilihat pada tabel berikut:
Pada Tabel 4.3 dapat dilihat bahwa semua item pertanyaan valid dan dapat di masukkan kedalam sistem.

\section{Penutup}

\subsection{Kesimpulan}

Berdasarkan hasil pembahasan dan pengujian sistemRancang Bangun Aplikasi Kamus Bahasa Indonesia - Bahasa Aceh Menggunakan Metode Rule Based Berbasis Android dapat disimpulkan bahwa:

1. Aplikasi AcehI dirancang menggunakan Eclipse dan dapat berjalan secara sempurna di smartphone android.

2. Aplikasi ini bermanfaat bagi user dalam proses penerjemahan, hal ini dapat dibuktikan dari kuisioner.

3. Perancangan aplikasi AcehI berhasil dan secara fungsional mengeluarkan hasil yang sesuai dengan yang diharapkan.

\subsection{Saran}

Aplikasi AcehI ini masih memiliki keterbatasan, baik dari cara rancangan maupun manfaat yang dihasilkan, maka terdapat beberapa saran sebagai pengembangan untuk kedepan.

1. Menambahkan kosakata untuk memperbanyak arti kata dalam Bahasa Aceh.

2. Mengembangkan aplikasi AcehI menjadi terjemahan kalimat.

3. Menambahkan fitur audio agar pengguna mengerti cara pengucapan dalam Bahasa Aceh.

Selain itu, aplikasi AcehI juga masih berjalan dalam keadaan offline diharapkan untuk kedepannya dapat dikembangkan lagi dan dapat menghasilkan manfaat yang lebih besar dari pada aplikasi yang sudah dirancang dan dibuat.

Tabel 4.3 Tabel Uji Validitas dan Reliabilitas 
Journal of Informatics and Computer Science Vol. 4 No. 1 April 2018

Universitas Ubudiyah Indonesia

e-ISSN : 2615-5346

\begin{tabular}{|c|c|l|}
\hline Item & Nilai Korelasi & \multicolumn{1}{|c|}{ Validitas Item } \\
\hline 1 & $\mathbf{0 . 6 4 1 2}$ & Valid \\
\hline 2 & $\mathbf{0 . 5 6 1 9}$ & Valid \\
\hline 3 & $\mathbf{0 . 7 6 2 2}$ & Valid \\
\hline 4 & $\mathbf{0 . 6 9 4 3}$ & Valid \\
\hline 5 & $\mathbf{0 . 6 3 3 0}$ & Valid \\
\hline 6 & $\mathbf{0 . 6 8 4 5}$ & Valid \\
\hline 7 & $\mathbf{0 . 6 8 4 5}$ & Valid \\
\hline
\end{tabular}


Journal of Informatics and Computer Science Vol. 4 No. 1 April 2018

Universitas Ubudiyah Indonesia

e-ISSN : 2615-5346

\section{DAFTAR PUSTAKA}

A.S Rosadan Shalahuddin M. 2013. Rekayasa

PerangkatLunak Terstruktur

danBerorientasiObjek.Bandung:Informatik

aBandung.

Ardian, Zalfie. 2014. Argot : Sistem Pendeteksian

Berbasis Text Secara Real Time

Menggunakan Augment Reality Sebagai

Media Translator Aceh - Indonesia

Dengan Smartphone Berbasis

Android.Tesis.Yokyakarta : Universitas

Gadjah Mada.PadaAmalia Computer

\&Accessories".

Burnette, Ed. 2010. Hello Android : Introducing Google's Mobile Development Platform $3^{\text {rd }}$ Edition, Pragmatic Programmers LLC, United States of America. Pada Mediafire File Sharing.Diakses 23 Oktober 2015.

Mutiawani, Viska dkk.2009. Aplikasi Kamus Dwibahasa Aceh Indonesia Berbasis Java Untuk Telepon Genggam. Jurnal Ilmiah. Banda Aceh : Universitas Syiah Kuala.

Pratama, I Putu Deni dan Agus Mulaintara. 2012.

Perancangan dan Implementasi Sistem Penerjemah Teks Bahasa Inggris ke Bahasa Bali Dengan Menggunakan Pendekatan Berbasis Aturan (Rule Based). Jurnal Ilmu Komputer - Vol 5 No 1 Bali : Universitas Udayana.

SafaatH,Nazruddin.2012.Pemrograman AplikasiMobileSmartphonedanTabletPC BerbasisAndroid.Bandung:

InformatikaBandung.

SafaatH,Nazruddin.2013.AplikasiBerbasisAndroi

dBerbagaiImplementasi dan

Pengembangan

AplikasiMobileBerbasisAndroid.Bandung

:Informatika Bandung.

Turban, Efraim, R.Kelly Rainer JR, Richard E.Potter, 2006. Pengantar Teknologi Informasi.

Salemba, Jakarta.

Widodo B, 2005. Panduan Lengkap Pemrograman. J2EE, ANDI, Yogyakarta. 